Originalartikkel

\title{
Farmakoterapi i sykehjem
}

\section{Sammendrag \\ Bakgrunn. Sykehjemspasientenes polyfarmasi, multimorbiditet og fysiolo- giske aldersforandringer gir høy risiko for legemiddelrelaterte problemer. Vi beskriver legemiddelforbruket og sam- menlikner legemiddelbehandlingen ved to sykehjem med ulik legedekning.}

\begin{abstract}
Materiale og metode. Vi inkluderte 48 langtidspasienter fra to sykehjem i Oslo, sykehjem A (24 pasienter) og sykehjem B (24 pasienter). En farmasøyt innhentet informasjon om legemiddelbruk, identifiserte og klassifiserte legemiddelrelaterte problemer og graderte legemidlene etter antikolinerg aktivitet. To leger med erfaring fra geriatri og sykehjemsmedisin vurderte, uavhengig av hverandre og blindet for hvilket sykehjem pasientene tilhørte, den kliniske betydningen av de legemiddelrelaterte problemene.
\end{abstract}

Resultater. Pasientene i sykehjem A brukte median (interkvartilavstand) 7,0 $(5,3-11,0)$ legemidler, sammenliknet med $9,5(8,0-12,8)$ i sykehjem B (median differanse 2,0, $95 \% \mathrm{KI}$ 1,0-4,0, $p=0,006$ ). Pasientene i sykehjem $A$ hadde også lavere antikolinerg skår enn pasientene i sykehjem $B-1,0$ $(0,0-2,0)$ mot $2,0(2,0-3,8)$ (median

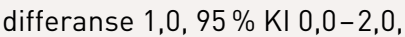
$p=0,009)$ - og færre legemiddelrelaterte problemer $-3,0(2,0-4,0)$ versus $5,5(3,3-8,0)$ (median differanse 2,0 , $95 \% \mathrm{KI} 0,0-3,0, p=0,007)$. Det var ingen signifikante forskjeller mellom sykehjemmene i pasientenes alder, komorbiditet, nyrefunksjon eller demensstatus, men legebemanningen var bedre i sykehjem $A$.

Fortolkning. Legemiddelforbruket så vel som kvalitetsindikatorene varierer betydelig mellom sykehjem. Ulik legedekning er én mulig forklaring på forskjellene. Undersøkelsen synliggjør behovet for tverrfaglige legemiddelgjennomganger som kvalitetshevende tiltak i sykehjemsmedisinen.

\section{Hege Kersten}

hege.kersten@farmasi.uio.no

Undervisningssykehjemmet i Oslo

Abildsø bo- og rehabiliteringssenter

Løvsetdalen 2

1188 Oslo

og

Geriatrisk avdeling

Oslo universitetssykehus, Ullevål

\section{Sabine Ruths}

Allmennmedisinsk Forskningsenhet i Bergen Unifob Helse

og

Institutt for samfunnsmedisinske fag

Universitetet i Bergen

Torgeir Bruun Wyller

Universitetet i Oslo

og

Geriatrisk avdeling

Oslo universitetssykehus, Ullevål

Rasjonell farmakoterapi i sykehjem kompliseres av stadig sykere pasienter som behandles med et økende antall legemidler med komplekse virkningsmekanismer. Sykehjemspasientenes multimorbiditet, organ- og mentalsvikt, alder og ernæringstilstand påvirker legemiddeleffekter og gjør legemiddelbehandlingen til et krevende felt. I den senere tid er legemiddelrelaterte problemer i økende grad blitt benyttet som kvalitetsindikator for farmakoterapi. Et legemiddelrelatert problem er definert som «en hendelse eller et forhold som skjer i forbindelse med legemiddelbehandlingen, og som reelt eller potensielt interfererer med ønsket helseeffekt» (1). Det er utarbeidet en norsk klassifisering av slike problemer (2). En undersøkelse med 1354 langtidspasienter over 65 år i sykehjem i Bergens-området viste at $76 \%$ hadde ett eller flere legemiddelrelaterte problemer (3). I en tilsvarende undersøkelse med 827 pasienter fra fem ulike sykehus fant man minst ett legemiddelrelatert problem hos $81 \%(4,5)$.

Tidligere studier indikerer at samlet medikamentell antikolinerg belastning er assosiert med kognitiv svekkelse, reduserte motoriske funksjoner og økt pleiebehov hos eldre (6-8). Likevel er det relativt vanlig å forskrive legemidler med høy antikolinerg aktivitet til eldre sykehjemspasienter (9).

I 2007 var gjennomsnittlig legedekning i norske sykehjem 120 pasienter per hele legestilling $(18,6$ minutter per uke per beboer), men legetilbudet varierer betydelig, også innenfor samme kommune (10). Vi studerte legemiddelforbruket og kvaliteten på legemiddelbehandlingen ved to sykehjem i Oslo med ulik legedekning. Vi brukte lege- middelrelaterte problemer og en skår på medikamentindusert antikolinerg belastning som kvalitetsindikatorer.

\section{Materiale og metode}

Vi inkluderte 48 pasienter, 24 fra sykehjem A og 24 fra sykehjem B. De ble selektert etter antatt samtykkekompetanse. I sykehjem A ble deltakerne rekruttert fra tre langtidsavdelinger med til sammen 66 pasienter, og det var legen som vurderte deres samtykkekompetanse. I sykehjem B ble deltakerne rekruttert fra én langtidsavdeling med 34 pasienter, og deres samtykkekompetanse ble vurdert av avdelingssykepleier. Samtykke ble innhentet fra alle. Samtidig fikk pårørende skriftlig informasjon om prosjektet kombinert med en reservasjonsrett dersom pasientens samtykkekompetanse likevel skulle være redusert.

Sykehjem A hadde en fulltidsansatt lege med ansvar for 94 pasienter, tilsvarende en dekningsgrad på ca. 24 minutter per pasient per uke. Langtidsavdelingen ved sykehjem B hadde en tilsynslege fra bydelen en dag $\mathrm{i}$ uken, tilsvarende en dekningsgrad på ca. 11 minutter per pasient per uke (gjennomsnittlig legedekning i Oslo i 2007 var 17,4 minutter per uke per beboer) (10). Begge sykehjemmene var bemannet med 3-4 sykepleiere per avdeling (ca. 34 pasienter) per døgn, mens sykehjem A var bedre bemannet med hjelpepleiere og pleieassistenter $(12-14$ pleiere versus 7-12 pleiere per 34 pasienter per døgn).

Prosjektet fikk tilrådning av regional komité for medisinsk forskningsetikk og ble godkjent av Datatilsynet. Sosial- og helsedirektoratet godkjente innsyn i pasientenes journaler.

\section{Hovedbudskap}

- Det var signifikant forskjell mellom to sykehjem når det gjaldt legemiddelforbruk, medikamentell antikolinerg belastning og antall legemiddelrelaterte problemer

- I sykehjemmet med lavest legedekning ble det brukt flest medikamenter og det var lavere kvalitet på legemiddelbehandlingen

- Jevnlige tverrfaglige legemiddelgjennomganger kan være et kvalitetshevende tiltak i norsk sykehjemsmedisin 
Tabell 1 Eksempler på gradering av legemiddelrelaterte problemer etter klinisk betydning for pasientene

Klinisk

gradering

og definisjon

Eksempler

fra materialet
Svært alvorlig

Legemiddelrelaterte problemer kan forårsake død eller irreversibel legemiddelindusert sykdom av alvorlig karakter

Pasient med tidligere ulcus. Har diaré, epigastriesmerter, blodig oppkast, svart avføring, vekttap. Får kapsler med melkesyrebakterier og en silikonforbindelse for sine magesmerter

Vurdering: Manglende behandling for klare symptomer på residiv av ulcus

Kategori legemiddelrelatert problem behov for tilleggsbehandling
2 Alvorlig

Legemiddelrelaterte problemer kan forårsake reversibel forverring av sykdom av alvorlig karakter

Pasient i slutten av 90-årene som gjennomgikk hjerneslag fem år tidligere og senere har utviklet amyotrofisk lateral sklerose. Bruker warfarin Vurdering: Warfarin kan seponeres da farmakologisk risikointervensjon synes lite meningsfullt hos en så gammel pasient med annen sykdom med alvorlig prognose

Uhensiktsmessig legemiddelvalg, Unødvendig legemiddel
3

Moderat alvorlig Legemiddelrelaterte problemer kan forårsake unødvendig belastning

Pasient som får levotyroksin og jern samtidig Vurdering: Samtidig inntak av jern medfører redusert absorpsjon av levotyroksin. Bør doseres med 2-3

timers mellomrom

$$
\text { mangler }
$$
Liten betydning Legemiddelrelaterte problemer krever en justering for optimal legemiddelbehandling

Tidvis uklar pasient som bruker to typer øyedråper: Timolol kombinasjonspreparat og en prostaglandinanalog Vurdering: Pasienten har trolig glaukom, men dokumentasjon på indikasjon og dosering

Ikke-optimalt doserings- Uklar kurveføring tidspunk
Pasientenes alder, kjønn, vekt, diagnoser, medisinlister (preparatnavn, styrke, dosering, fast eller behovsmedisin) og laboratoriedata ble registrert av en farmasøyt med erfaring fra klinisk farmasi i sykehus (HK). Pasientenes glomerulusfunksjon (GFR) ble beregnet ut fra formelen Modification of Diet in Renal Disease (MDRD) (11). Vi brukte Charlsons komorbiditetsindeks som samlemål på pasientenes sykelighet (12). Sykehjemsansatte med god kjennskap til pasientene vurderte deres kognitive funksjonsnivå ved hjelp av skalaen klinisk demensvurdering (KDV), en internasjonalt standardisert skala som er oversatt og tilpasset norske forhold (13). For å kartlegge bruken av antikolinerge legemidler brukte vi et publisert klassifiseringssystem der legemidlene har en antikolinerg skår fra 0 til $3(0=$ ingen antikolinerg aktivitet, $3=$ høy antikolinerg aktivitet), basert på reseptorbindingsstudier og/eller klinisk dokumenterte antikolinerge effekter (14).

Farmasøyten identifiserte legemiddelrelaterte problemer på bakgrunn av innhentede medisinske opplysninger, og klassifiserte dem i samsvar med det norske klassifiseringssystemet. Dette er hierarkisk og består av seks hovedkategorier med 12 underkategorier (2). Også manglende adekvat legemiddelbehandling er inkludert i systemet. To leger med spisskompetanse $i$ henholdsvis allmennmedisin/sykehjemsmedisin (SR) og indremedisin/geriatri (TBW) vektet de identifiserte problemene i kategoriene svært alvorlig, alvorlig, moderat alvorlig eller av liten klinisk betydning for pasienten. Legene arbeidet uavhengig av hverandre og blindet for hvilket sykehjem pasientene tilhørte. Graderingen av klinisk betydning ble gjort i samsvar med en tidligere publisert modell (5) (tab 1). Der legenes vurdering var forskjellig, ble endelig klassifisering fastsatt ved en konsensusdiskusjon. Sykehjemmene har i ettertid fått tilbud om en gjennomgang av pasientenes legemiddelbehandling sammen med farmasøyten for å diskutere mulige terapeutiske intervensjoner.

Alle sentralmål er oppgitt som medianverdi og variansen som interkvartilavstand (IKA) om ikke annet er angitt. Ved sammenlikning av gruppene har vi benyttet Mann Whitneys test og tilsvarende metode for beregning av konfidensintervall. Signifikansnivå for forkasting er satt til $\mathrm{p}<0,05$. Analysene er gjort med statistikkprogrammene SPSS og Confidence Interval Analysis (15).

\section{Resultater}

Av 50 forespurte pasienter var det to som ikke samtykket. Ingen pårørende benyttet seg av reservasjonsretten. Ved begge sykehjemmene ble det tilfeldigvis lik kjønnsfordeling, sju menn og 17 kvinner. Tabell 2 viser deskriptive data for de to gruppene. Det var ingen signifikante forskjeller i alder, nyrefunksjon, KDV-status eller komorbiditet mellom pasientgruppene, men KDV-skåringen indikerte en ikke-signifikant trend $\mathrm{i}$ retning av at pasienter med mer alvorlig demens var inkludert ved sykehjem B. $77 \%$ av pasientene hadde redusert nyrefunksjon (GFR $<90 \mathrm{ml} / \mathrm{min} / 1,73 \mathrm{~m}^{2}$ ), og Charlsons komorbiditetsindeks viste en betydelig sykelighet.

Medianverdien for legemiddelforbruket til alle sykehjemspasientene var åtte faste legemidler (6-12 faste legemidler) (inkludert vitaminer og kosttilskudd), og forbruket var signifikant lavere ved sykehjem A enn ved sykehjem B (tab 3). Ved sykehjem A brukte seks pasienter et multivitaminpreparat, mot 12 ved sykehjem B.

Mediant antall legemiddelrelaterte problemer per pasient $\mathrm{i}$ begge sykehjem samlet var $4,0(2,0-6,8)$, og $30 \%$ av problemene ble vurdert som alvorlige. Tabell 3 viser legemiddelrelaterte problemer gradert etter klinisk betydning ved hvert sykehjem. Ved sykehjem A fant vi median 3,0 $(2,0-4,0)$ legemiddelrelaterte problemer per pasient. Én av 24 pasienter hadde ingen identifiserte problemer. Mediant antall legemiddelrelaterte problemer per pasient ved sykehjem B var $5,5(3,5-8,0)$, og alle pasientene ved dette sykehjemmet hadde minst ett legemiddelrelatert problem. Forskjellen i legemiddelrelaterte problemer er statistisk signifikant. Ved sykehjem B var det en betydelig større andel klinisk alvorlige problemer og en høyere skår for medikamentell antikolinerg belastning (tab 3).

Mange av de legemiddelrelaterte problemene var knyttet til bruken av diuretika, sedativer, antipsykotika, antikolinerge legemidler (trisykliske antidepressiver, antihista-

Tabell 2 Karakteristika ved pasientene. Median (interkvartilavstand)

\begin{tabular}{lccc} 
& Sykehjem A & Sykehjem B & $\begin{array}{c}\text { P-verdi } \\
\text { (Mann Whitneys test) }\end{array}$ \\
\hline Alder lår) & $86,5(76,0-90,0)$ & $87,0(83,0-91,6)$ & 0,374 \\
\hline $\begin{array}{l}\text { Glomerulusfunksjon (GFR), } \\
\text { (ml/min/1,73 m²) }\end{array}$ & $69,0(63,0-82,0)$ & $75,0(55,3-94,8)$ & 0,913 \\
\hline $\begin{array}{l}\text { Skår på klinisk demens-vurdering } \\
\text { (KDV) }\end{array}$ & $1,0(1,0-1,8)$ & $1,0(1,0-3,0)$ & 0,075 \\
\hline Charlsons komorbiditetsindeks ${ }^{1}$ & $2,0(1,0-3,8)$ & $3,0(2,0-4,0)$ & 0,913 \\
\hline Legetid per pasient per uke (min) & 24 & 11 &
\end{tabular}

${ }^{1} \mathrm{KDV}=0-3$, der høyere skår indikerer mer alvorlig demens

${ }^{2}$ Høyere skår indikerer mer uttalt komorbiditet 


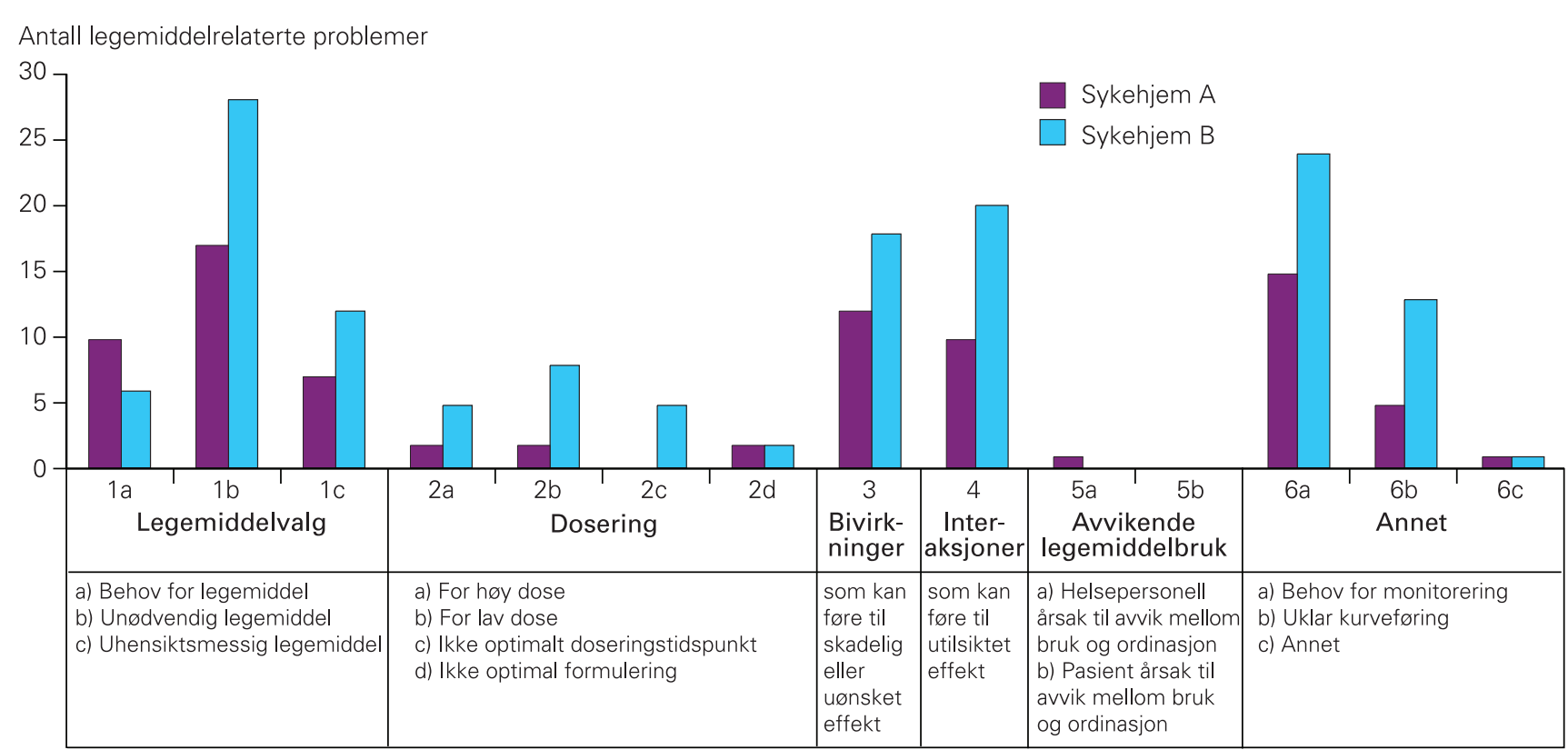

Figur 1 Klassifisering av legemiddelrelaterte problemer hos 48 sykehjemspasienter (2)

miner og legemidler mot inkontinens), ikkesteroide antiinflammatoriske midler, paracetamol og opioider.

Figur 1 viser klassifiseringen av de legemiddelrelaterte problemene. Ved begge sykehjemmene utgjorde bruk av unødvendige legemidler og manglende monitorering nesten $40 \%$ av totalt antall identifiserte problemer. Vi fant 22 (sykehjem A) versus 38 (sykehjem B) legemiddelrelaterte problemer knyttet til interaksjoner og bivirkninger, og det var også flere problemer i kategorien uklar dokumentasjon ved sykehjem B.

\section{Diskusjon}

Vi fant et høyt legemiddelforbruk og et høyt antall legemiddelrelaterte problemer i begge de undersøkte sykehjemmene, men også en påfallende stor forskjell mellom dem. Det er tidligere vist at det er en nær sammenheng mellom antall legemidler brukt og antall legemiddelrelaterte problemer funnet (16). Unødvendig legemiddelbruk og manglende monitorering av behandlingen var de to største problemkategoriene ved begge sykehjemmene (fig 1). En norsk undersøkelse viste sterk sammenheng mellom oppholdstid i sykehjem og legemiddelbehandlingenes varighet, og indikerer at instituert behandling har en tendens til å vare lenge (17).

Skår for antikolinerg belastning ble brukt som en kvalitetsindikator i denne undersøkelsen, og pasientene i sykehjem A hadde en signifikant lavere skår enn pasientene i sykehjem B. Flere undersøkelser tyder på at legemiddelindusert antikolinerg aktivitet er uheldig for motoriske og kognitive funksjoner hos eldre (7-9). Våre resultater indikerer et mulig potensial for redusert bruk av legemidler med antikolinerge effekter i sykehjem. Den kliniske betydningen av å redusere legemiddelindusert antikolinerg aktivitet bør imidlertid studeres nærmere.

Det var betydelig forskjell mellom sykehjemmene når det gjaldt legemiddelforbruk og antall legemiddelrelaterte problemer. Vi fant ingen signifikante forskjeller i pasientenes alder, sykelighet eller nyrefunksjon som kunne forklare dette. Riktignok var det en statistisk ikke-signifikant forskjell i klinisk demensstatus, men det er lite trolig at denne forklarer forskjellen i legemiddelforbruk. Vi kan imidlertid ikke utelukke seleksjonsskjevhet, da legen rekrutterte pasientene fra tre

Tabell 3 Legemiddelbruk og legemiddelrelaterte problemer hos sykehjemspasienter $(n=48)$

\begin{tabular}{|c|c|c|c|c|}
\hline & $\begin{array}{c}\text { Sykehjem A } \\
\text { Median (interkvartilavstand) }\end{array}$ & $\begin{array}{c}\text { Sykehjem B } \\
\text { Median (interkvartilavstand) }\end{array}$ & $\begin{array}{l}\text { Median differanse } \\
\qquad(95 \% \mathrm{KI})\end{array}$ & $\begin{array}{c}\text { P-verdi } \\
\text { (Mann-Whitneys } \\
\text { test) }{ }^{1}\end{array}$ \\
\hline Antall faste ordinasjoner & $7,0(5,3-11,00)$ & $9,5(8,0-12,8)$ & $2,0(1,0-4,0)$ & 0,006 \\
\hline Antall ordinasjoner ved behov & $2,0(0,3-5,0)$ & $4,0(3,0-5,0)$ & $1,0(0,0-1,0)$ & 0,088 \\
\hline Antikolinerg legemiddelskår² & $1,0(0,0-2,0)$ & $2,0(2,0-3,8)$ & $1,0(0,0-2,0)$ & 0,009 \\
\hline $\begin{array}{l}\text { Svært alvorlige og alvorlige legemiddel- } \\
\text { relaterte problemer }{ }^{3}\end{array}$ & $1,0(0,0-1,0)$ & $2,0(0,3-3,0)$ & $1,0(0,0-2,0)$ & 0,060 \\
\hline $\begin{array}{l}\text { Moderat alvorlige legemiddelrelaterte } \\
\text { problemer }\end{array}$ & $2,0(1,0-2,0)$ & $3,0(1,3-5,0)$ & $1,0(0,0-3,0)$ & 0,003 \\
\hline $\begin{array}{l}\text { Legemiddelrelaterte problemer med liten } \\
\text { klinisk betydning }\end{array}$ & $1,0(0,0-1,0)$ & $1,0(0,0-1,0)$ & $0,0(0,0-3,0)$ & 0,345 \\
\hline $\begin{array}{l}\text { Totalt antall legemiddelrelaterte proble- } \\
\text { mer }\end{array}$ & $3,0(2,0-4,0)$ & $5,5(3,3-8,0)$ & $2,0(1,0-4,0)$ & 0,007 \\
\hline
\end{tabular}


avdelinger i sykehjem A, mens avdelingssykepleieren rekrutterte pasientene fra én avdeling i sykehjem B.

Det er nærliggende å tenke seg at forskjeller i faglig standard mellom de to sykehjemmene har betydning for kvaliteten av farmakoterapien. Ulikheter i personalets kunnskaper, holdninger og ferdigheter, eksempelvis i ikke-farmakologisk behandling av atferdsforstyrrelser ved demens, vil kunne ha betydning for medisineringen av pasientene.

Sykehjem A hadde et bedre legetilbud og en noe høyere pleierbemanning enn sykehjem B. Legedekningen ved sykehjem A tilsvarte Legeforeningens tidligere foreslåtte bemanningsnorm; én sykehjemslege per 90 langtidspasienter (18). Det var klart høyest kvalitet på legemiddelbehandlingen ved sykehjem A. Det er rimelig å anta at bedre tid og kontinuitet gir sykehjemslegene større mulighet for jevnlig evaluering og tettere oppfølging av den medisinske behandlingen til langtidspasientene. Jevnlige, tverrfaglige legemiddelgjennomganger vil trolig kunne redusere legemiddelforbruket, redusere risikoen for legemiddelrelaterte problemer og gi en legemiddelbehandling som er bedre tilpasset pasientens aktuelle kliniske situasjon. Kontinuitet er også en viktig forutsetning for sykehjemslegens mulighet til å bidra til andre kvalitetshevende tiltak, slik som internundervisning i farmakoterapi eller systematisk vurdering av smerte (19) og atferdsforstyrrelser (20) hos pasienter med demens.

Legemiddelrelaterte problemer er uttrykk for en potensiell risiko, og innebærer ikke nødvendigvis negative helseeffekter. I vår undersøkelse er alle legemiddelrelaterte problemer vurdert av to klinikere blindet for pasientenes sykehjemstilhørighet. Vi mener dette styrker bruken av legemiddelrelaterte problemer som en klinisk relevant kvalitetsindikator på legemiddelbehandlingen, men undersøkelsens størrelse og teoretiske endepunkt gjør at resultater bør tolkes varsomt.

Likevel mener vi at resultatene tydeliggjør behovet for jevnlige legemiddelgjennomganger i sykehjem. Et tverrfaglig klinisk-farmakologisk samarbeid mellom lege og farmasøyt kan være hensiktsmessig ved legemiddelgjennomganger i geriatrien, der balansen mellom medisinenes effekt og risiko kan være særlig vanskelig å vurdere. Slike gjennomganger reduserer likevel ikke behovet for tilstrekkelige legeressurser $\mathrm{i}$ institusjonene.

Oppgitte interessekonflikter: Ingen

Vi takker Gerd Torbjørg Åmdal for nyttige innspill og engasjement.

Litteratur

1. Pharmaceutical Care network Europe. PCNE Classification for drug-related problems V5.01. www.pcne.org/dokumenter/DRP/

PCNE\%20classification \%20V5.01.pdf (30.3.2009)
2. Ruths S, Viktil KK, Blix HS. Klassifisering av legemiddelrelaterte problemer. Tidsskr Nor Lægeforen 2007; 127: 3073-6.

3. Ruths S, Straand J, Nygaard HA. Multidisciplinary medication review in nursing home residents: what are the most significant drug-related problems? The Bergen District Nursing Home (BEDNURS) study. Qual Saf Health Care 2003; 12 $176-80$

4. Viktil KK, Blix HS, Reikvam A et al. Comparison of drug-related problems in different patient groups. Ann Pharmacother 2004; 38: 942-8.

5. Blix HS, Viktil KK, Reikvam A et al. The majority of hospitalised patients have drug-related problems. Results from a prospective study in general hospitals. Eur J Clin Pharmacol 2004; 60: 651-8.

6. Mulsant BH, Pollock BG, Kirshner M et al. Serum anticholinergic activity in a community-based sample of older adults. Relationship with cognitive performance. Arch Gen Psychiatry 2003; 60 : $198-203$.

7. Nebes RD, Pollock BG, Halligan EM et al. Serum anticholinergic activity and motor performance in eldery persons. J Gerontol A Biol Sci Med Sci 2007: 62A: $83-5$.

8. Landi F, Russo A, Liperrotu R et al. Anticholinergic drugs and physical function among frail elderly population. Clin Pharmacol Ther 2007; 81: 235-41.

9. Ruths $S$. Evaluation of prescribing quality in nursing homes based on drug-specific indicators: the Bergen district nursing home (BEDNURS) study. Norsk Epidemiologi 2008; 18: 173-8.

10. Statistisk sentralbyrå. http://statbank.ssb.no/ statistikkbanken/Default_FR.asp?PXSid=0\&nvl $=$ true $\&$ PLanguage $=0 \&$ tilside $=$ selectvarval/ define. asp\&Tabellid=04930 (30.3.2009)

11. National Kidney Foundation. www.kidney.org/ professionals/tools (30.3.2009)

12. Charlson ME, Pompei P. Ales KL et al. A new method of classifying prognostic comorbidity in longitudinal studies: development and validation. J Chronic Dis 1987; 40: 373-83.
13. Lystrup LS, Lillesveen B, Nygård AM et al. Omsorgstilbud til hjemmeboende personer med demens. Tidsskr Nor Lægeforen 2006; 126 : 1917-20.

14. Carnahan RM, Lund BC, Perry PJ et al. The anticholinergic drug scale as a measure of drugrelated anticholinergic burden: association with serum anticholinergic activity. J Clin Pharmacol 2006; 46: 1481-6.

15. Gardner M. Confidence Interval Analysis, version 1.1 (dataprogram). London: British Medical Journal, 1991.

16. Viktil KK, Blix HS, Moger TA et al. Polypharmacy as commonly defined is an indicator of limited value in the assessment of drug-related problems. Br J Clin Pharmacol 2006; 63: 187-95.

17. Nygaard HA. Varighet av legemiddelbruk i sykehjem. Tidsskr Nor Lægeforen 2001; 121: 1469-71.

18. Bemanningsnormer i sykehjem. Økt bemanning gir bedre sykehjemstjenester. Legeforeningens policynotat nr. 2/2005. Oslo: Den norske lægeforening, 2005. www.legeforeningen.no/id/87559.0 (30.3.2009).

19. Husebø BS. Assessment of pain in patients with dementia. Doktoravhandling. Bergen: Institutt for samfunnsmedisinske fag, Universitetet i Bergen, 2008

20. Selbæk G. Behavioural and psychological symptoms of dementia in Norwegian nursing homes. Doktoravhandling. Oslo: Det medisinske fakultet, Universitetet i Oslo, 2008.

Manuskriptet ble mottatt 5.5. 2008 og godkjent 16.4. 2009. Medisinsk redaktør Erlend Hem. 